\title{
The optimization of banking regulation intensity from the perspective of financial stability in banking sector: an empirical analysis
}

\author{
Oksana Didenko
}

Retail Business Manager, Kharkiv oblast Directorate of JSC Raiffeisen Bank Aval, Ukraine

Slavoljub Dordevic

Consumer \& Small Business Banking, Raiffeisen Bank International AG, Austria

(C) The Authors, 2017. This article is published with open access at ARMG Publishing.

\begin{abstract}
This paper investigates a multifactorial model, which allows defining an optimum level of banking regulation intensity based on the provision of a financial stability (at the macrolevel) and financial stability of banks (at the microlevel). An aggregated index of banking regulation intensity as well as an integrated index of financial stability of banks, which were the main factorial and resultative characteristic features during investigations, was formed for carrying-out of an empirical analysis. The optimum level of intensity of banking regulation has been suggested to define as the extremum of function of integrated index of financial stability of banks (determined by the method of the uniform optimality) on the relevant influencing factors (method of principal components).
\end{abstract}

Keywords: financial sustainability, financial stability, banking regulation, optimization control.

JEL Classification: E50, F30, G21.

\section{Introduction}

Under the conditions of refocusing of regulatory policy to protection from systemic risks by macroprudential regulation and increasing the priority interests of the financial system over the individual interests of its members, the issue of financial stability turns into one of the fundamental reasons of state. From the point of view of business, the stability of financial standing of banks is one of the principal criteria and indicators of financial stability. That is why in general terms state interest is aligned with a financial stability in whole (the macrolevel), and business interest - with a financial sustainability of the bank (the microlevel). The financial and economic crisis and destabilizing processes in financial systems of many countries across the world make actual the questions of reforming approaches to bank regulation and monitoring. Modern transformation of regulatory initiatives on the implementation of banking activity is characterized by the replacement of prudential supervision, based on individual banks risks, to macroprudential, aimed at considering risks all around the financial system; spectrum broadening the objectives of central banks and the respective tools of banking regulation to ensure not only the price but also financial stability. At present, the regulation of banking activities is particularly topical issue, because a state of the overall economy depends on the stable and consistent operation of banks and the system. For the moment, a variety of international organizations are responsible for the steady monitoring and supervision over the banking institutions that are members of these organizations. Determining the stability or instability of the banking system, we operate with a set of indicators upon which its overall quantitative or qualitative estimate is made. The regulatory process, in turn, is quite a complex concept and is not limited by the choice of one indicator whereby you can evaluate the hardness or softness of the activities of the regulatory process. Besides, when identifying the relationship between the directions of regulation and the stability of the banking system, there is a need to consider country specifics, where the research is conducted, the level of its economic development, which dictate the need for a complex approach in the process of analysis of bank regulation system and its influence on basic macroeconomic characteristics of the banking sector functioning in the context of the selection of optimal variants of the regulatory impact on the financial stability of the banking system and financial sustainability of individual banks. 


\section{Literature review}

In Ukrainian scientific literature, studies, dedicated to the identification of the concept "financial stability", the determination of key factors of influence and tools of its securing. This problematic does not lose its edge today, as Ukrainian financial system is in the process of reforming under the conditions of structural changes, caused by economic crises, unstable political and geopolitical situation in the country. So, I.V. Belova and S.V. Bashlai [4] consider the availability of reliable buffers in the domestic banking system, which can be laid at the expense of bank capital, liquidity, trust in banks and their reliability as the major premises of the definition of financial stability in Ukraine; it is necessary to take into account the functional purpose of the financial system, which is formed to ensure the serving the interests of public and private sectors; the financial stability of Ukraine depends on a wide range of micro- and macroeconomic factors. As to the ratio of financial stability and banking system stability, per Y.V. Belinskaya and the group of Ukrainian researchers headed by S.G. Arbuzov [2] respectively, the financial stability is a key property of the financial system, which is characterized by the minimum amount of the costs required to change the basic characteristics of its development in accordance with the processes of transformation of economic systems and external influences. But the stability of the banking system should be construed as an integrated assessment of the state of the banking system, in which its essence and key appointment in the economic system of the state are realized, its functions are adequately and effectively fulfilled; and the ability to maintain equilibrium position and the recovery after external and internal structural changes provides.

The world community of states at determining the key indicators of financial stability uses the methodology of the International Monetary Fund. The National Bank of Ukraine, which identifies the financial stability in terms of 12 major and 10 recommended indicators, is no exception. Some native researchers have tried to offer some transformations of these indicators to display the integral index of financial stability of the banking system of Ukraine. In their work, V. Kovalenko and Y. Garkusha [23] developed an algorithm for the calculation of financial stability indicator of the banking system, which depends on the intermediate indicators of banking activity and random weight vector of averaged scores for each of the intermediate indicator. The steps of the algorithm were tested on the domestic banking system, resulting in the cyclical development of Ukrainian banking system of under the influence of the periodicity of the crisis onset.

In world scientific literature, considerable attention is paid to the quantitative analysis of the interaction between banking regulation and ensuring the stability of the banking system. M. Shahchera and N. Jouzdani [24] in their cooperative work studied the problem of this interaction. In the course of investigations, to describe the degree of banking system stability, authors have chosen Z-score, suggesting that the banking system stability should be understood as the probability of its financial insolvency - the assets quality of a bank is lower than the quality of its obligations. The authors have identified the factors that affect the financial stability of the banking system as a capital adequacy ratio, liquidity provision, return on assets, real GDP, GDP growth rate, which allowed drawing several conclusions based on the constructed model with fixed effects:

$>$ GDP growth ensures general economic development that is why it makes a positive impact on the banking system stability;

$>$ the stability index of banking system is also increased with the increase of capital adequacy ratio and return on assets (ROA);

$>$ the growth in liquidity reserve is adversely reflected on the ensuring the banking system stability.

At the beginning of their research the authors have developed a hypothesis that there is an inverse quadratic dependence between the regulation of banking activity and the stability of the banking system. As the result, this hypothesis was confirmed. This suggests that to the defined limit the regulation of banking activity has a positive effect upon the banking system stability and then begins negatively affect it.

Some other researches headed by J. Barth [3] took another approach to the assessment of banking regulation activity from the perspective of ensuring banking system stability. They examined 78 countries from around the world and constructively divided them based on two criteria: Mult and Cenban. These binary values are 1 or 0 . If the country under investigation has more than one supervisory authority in the banking system, the value of Mult is 1 , otherwise - 0 . If the banking system is regulated only by one authority, mostly by the central bank, then the meaning of Cenban equals to 1 , if not -0 , correspondingly. Further research was carried out with groups of countries, organized per this principle. The regression model was used as the analysis tool, 
in which dependent, independent and control variables were traditionally separated. The investigation of regression model was carried out based on the OLS-regression. Consequently, the analysis the following was revealed. The variables that characterize the capital and the liquidity risk of banks are sensitive to the number of supervisory bodies for banking activities. Increasing the number of supervisory bodies reduces the capital adequacy ratio by more than $2 \%$ and thus provokes the banking system to the onset of the risk of loss of its financial solvency, which is confirmed by a considerable increase in liquidity risk with an increase in the number of supervisory bodies in the country. Thus, the analysis of existing studies indicates the need for complex regulatory levers of influence in the construction of the optimum, in terms of ensuring financial stability of banks, system of banking regulation, the application of which must be accompanied by the analysis of the macroeconomic environment of the country and the phase of its economic development.

\section{Methodology}

During the study of theoretical positions of banking regulation and supervision and its relationship with the banking system stability, scientific methods (scientific abstraction, induction and deduction, analysis and synthesis, analogy method, etc.), as well as quantitative economic and mathematical methods were used in the process of conducting an empirical research of dependence of stability level of the banking sector on the banking regulation intensity in the country. In particular, at various stages of calculation the min-max method (when constructing the aggregated indicator of the intensity of banking activity regulation in the country), the method of uniform optimality (when calculating the integral index of the banking system stability); the correlation analysis (upon examination of the integral index components of the banking system stability for multicollinearity) the method of principal components (in the determination of relevant factors of influence on the financial stability of banks); the panel regression analysis on the basis of multifactor models with fixed effects (for quantitative estimation of dependence of the banking sector stability on the intensity level of banking regulation in the country) were used.

\section{Findings}

The evaluation of banking regulation intensity is proposed to carry out with the help of an approach that allows you to take into account such components of regulatory mechanism: 1) functional, which reflects the methodological basis of banking activity regulation (in particular, the intensity of monetary policy) and that is represented by instruments of indicative and administrative nature; 2) organizational, which reflects the costs on regulatory actions and is measured by the expenses on the implementation of regulatory activity, based on the number of staff involved; 3) institutional, which characterizes the institutional environment of the banking activity through the compliance of law principles and the level of financial freedom. It should be noted that the indicators that directly assess the intensity of banking activity regulation are in the public domain and therefore should be included in the basis for constructing an integral indicator intensity of banking activity regulation in the country (Table 1 ).

Table 1. Indicators included in the basis for constructing an integral intensity indicator of banking activity regulation in the country, and their sources

\begin{tabular}{|c|c|}
\hline Indicator & Source \\
\hline Obligatory reserve rate & Official websites of the central banks of countries \\
\hline The volatility of discount rate & Official websites of the central banks of countries \\
\hline $\begin{array}{l}\text { The implementation of Basel principles for banking super- } \\
\text { vision }\end{array}$ & Official websites of the central banks of countries \\
\hline $\begin{array}{l}\text { The presence of the Deposit Insurance Fund for bank's } \\
\text { customers }\end{array}$ & \multirow{2}{*}{$\begin{array}{l}\text { Official websites of the Bank for International Settlements } \\
\text { Official websites of the central banks of countries }\end{array}$} \\
\hline $\begin{array}{l}\text { The obligation of exposure of banks in the Deposit Insur- } \\
\text { ance Fund for customers }\end{array}$ & \\
\hline Interest rate caps on loans / deposits & Official websites of agencies of guaranteeing of clients' deposits \\
\hline \multicolumn{2}{|l|}{ Real interest rate } \\
\hline $\begin{array}{l}\text { The ratio between the number of employees at the central } \\
\text { bank and the number of banks and their branches }\end{array}$ & Official websites of the central banks of countries \\
\hline The compatibility index of law principles & Official website of the World Bank \\
\hline Financial Freedom Index & Official websites of the central banks of countries \\
\hline
\end{tabular}

Sources: 5-21, 26, 27. 
In the context of the study, 23 countries were selected, which are differed in terms of economic development, located in different geographical areas and have their unique features of banking industry and processes taking place in the banking system. The list of countries includes Ukraine, Germany, France, Britain, Russia, Kazakhstan, the USA, Belarus, Australia, Chile, India, Canada, Colombia, Malaysia, Brazil, Poland, the Netherlands, South Africa, the Philippines, Nigeria, Morocco, Estonia, Georgia. The 2001-2014 period was chosen for the study.

To control the intensity regulation of each selected parameters measured on the same scale of 0 to 1 , let's carry out the normalization of the following formulas:

$$
\begin{aligned}
& \frac{X_{i}-X_{\text {min }}}{X_{\text {max }}-X_{\text {min }}} ; \\
& \frac{X_{\text {max }}-X_{i}}{X_{\text {max }}-X_{\text {min }}},
\end{aligned}
$$

where $X_{i}$ - the indicator value of regulation in i-th year of the corresponding country; $X_{\min }$ - the minimum value of the index of regulation for the entire period of study in whole among the countries in question; $X_{\max }-$ the maximum value of the index of regulation for the entire period of study in whole among the countries under review.

Equation (1) is used when a larger value of the index reflects a high degree of regulation intensity of banking activity in the country, and equation 2 - if the lower indicator value of regulation indicates the higher degree of regulation intensity of banking activity by relevant authorities.

Note that from the list of control parameters we have chosen to build the integral intensity indicator of banking activity regulation almost all of them by increasing their quantitative values reflect the increase in the intensity of regulatory actions by relevant authorities. However, such indicators as the real interest rate and the index of financial freedom characterize the regulation intensity in a different way and thus were normalized using equation 2.

Following the normalization, 11 standardized values of banking activity regulation (from 0 to 1 ) were obtained, upon which their summation was accomplished. Following calculations, quantitative values of integral intensity indicator of banking activity regulation were obtained in Table 2. The results of the calculations indicate the prevalence of moderate and minor levels of state intervention in the banking business of surveyed countries, while there is a general trend of growth of banking regulation intensity in conditions of significant variation in the financial and macroeconomic stability as a result of the global financial and economic crisis.

Table 2. Normalized values of integral intensity indicator of banking regulation activity

\begin{tabular}{|l|l|l|l|l|l|l|l|l|l|l|l|l|l|l|}
\hline Country & 2001 & 2002 & 2003 & 2004 & 2005 & 2006 & 2007 & 2008 & 2009 & 2010 & 2011 & 2012 & 2013 & 2014 \\
\hline Ukraine & 4.54 & 4.49 & 4.36 & 4.85 & 4.86 & 4.43 & 4.58 & 4.65 & 4.62 & 4.85 & 5.11 & 5.42 & 5.56 & 5.64 \\
\hline Germany & 6.15 & 6.05 & 5.93 & 5.92 & 5.98 & 6.27 & 6.86 & 6.42 & 6.10 & 6.09 & 6.09 & 6.06 & 5.86 & 5.90 \\
\hline France & 6.09 & 5.96 & 5.88 & 5.93 & 5.97 & 6.18 & 6.65 & 6.23 & 5.92 & 5.95 & 5.93 & 5.88 & 5.80 & 5.79 \\
\hline UK & 4.41 & 4.43 & 4.42 & 4.48 & 4.43 & 4.55 & 5.05 & 4.77 & 4.69 & 4.84 & 4.79 & 4.79 & 4.80 & 4.87 \\
\hline $\begin{array}{l}\text { The Russian } \\
\text { Federation }\end{array}$ & 3.29 & 3.29 & 3.24 & 4.97 & 4.93 & 4.86 & 4.64 & 5.53 & 5.47 & 5.64 & 5.73 & 5.61 & 5.73 & 6.77 \\
\hline Kazakhstan & 4.00 & 4.02 & 4.57 & 4.54 & 4.59 & 4.17 & 4.38 & 4.18 & 4.12 & 4.32 & 5.35 & 5.31 & 5.50 & 5.28 \\
\hline The USA & 5.50 & 5.32 & 5.29 & 5.29 & 5.46 & 5.61 & 5.73 & 5.52 & 6.32 & 6.46 & 6.46 & 6.46 & 6.44 & 6.96 \\
\hline Belarus & 3.22 & 3.08 & 2.88 & 3.60 & 3.62 & 3.51 & 3.83 & 3.81 & 5.62 & 5.65 & 6.11 & 6.14 & 5.78 & 6.03 \\
\hline Australia & 3.27 & 3.32 & 3.43 & 3.42 & 3.43 & 3.56 & 3.68 & 5.78 & 5.73 & 5.81 & 5.80 & 5.56 & 5.47 & 5.56 \\
\hline Chile & 5.60 & 5.44 & 5.47 & 5.34 & 5.61 & 5.77 & 5.70 & 5.85 & 5.22 & 5.53 & 5.65 & 5.59 & 5.55 & 5.29 \\
\hline India & 6.71 & 6.40 & 6.30 & 6.04 & 6.07 & 6.30 & 6.95 & 6.62 & 6.08 & 6.45 & 7.81 & 7.58 & 7.50 & 6.44 \\
\hline Canada & 5.78 & 5.88 & 5.86 & 5.68 & 5.76 & 5.92 & 5.92 & 5.44 & 5.23 & 5.39 & 5.87 & 5.85 & 5.85 & 5.90 \\
\hline Colombia & 5.41 & 5.23 & 5.41 & 5.38 & 5.34 & 5.31 & 5.55 & 5.67 & 5.41 & 5.44 & 5.59 & 5.47 & 5.26 & 5.31 \\
\hline Malaysia & 2.87 & 2.91 & 2.94 & 2.97 & 5.04 & 5.04 & 4.91 & 4.88 & 4.44 & 4.54 & 4.75 & 4.69 & 4.69 & 5.64 \\
\hline Brazil & 4.50 & 6.05 & 5.65 & 5.74 & 5.71 & 5.55 & 5.65 & 5.78 & 5.41 & 5.94 & 6.42 & 6.21 & 6.30 & 6.42 \\
\hline Poland & 4.69 & 4.41 & 4.31 & 4.34 & 5.29 & 5.26 & 5.51 & 5.42 & 5.39 & 5.44 & 5.48 & 5.53 & 5.37 & 5.32 \\
\hline The Netherlands & 5.66 & 5.64 & 5.48 & 5.48 & 5.40 & 5.50 & 6.23 & 6.05 & 5.89 & 5.93 & 5.94 & 5.79 & 5.76 & 5.74 \\
\hline South Africa & 2.71 & 3.01 & 2.28 & 2.30 & 2.48 & 2.68 & 3.67 & 4.17 & 3.87 & 3.77 & 3.76 & 3.70 & 3.73 & 3.79 \\
\hline
\end{tabular}


Table 2 (cont.). Normalized values of integral intensity indicator of banking regulation activity

\begin{tabular}{|l|c|c|c|c|c|c|c|c|c|c|c|c|c|c|}
\hline Country & 2001 & 2002 & 2003 & 2004 & 2005 & 2006 & 2007 & 2008 & 2009 & 2010 & 2011 & 2012 & 2013 & 2014 \\
\hline The Philippines & 4.72 & 4.72 & 4.67 & 4.67 & 4.83 & 4.81 & 4.67 & 4.60 & 4.47 & 4.50 & 4.65 & 4.99 & 5.52 & 5.64 \\
\hline Nigeria & 3.92 & 4.27 & 4.02 & 3.90 & 4.18 & 4.32 & 3.73 & 3.67 & 4.26 & 4.18 & 3.83 & 3.82 & 3.92 & 5.05 \\
\hline Morocco & 5.25 & 5.34 & 5.38 & 5.35 & 5.51 & 5.39 & 5.20 & 5.57 & 5.06 & 4.73 & 4.79 & 4.56 & 4.39 & 5.43 \\
\hline Estonia & 4.77 & 4.43 & 4.25 & 4.30 & 4.38 & 4.71 & 4.83 & 4.60 & 4.15 & 5.18 & 5.26 & 5.19 & 5.12 & 5.10 \\
\hline Georgia & 3.21 & 3.13 & 2.79 & 2.36 & 2.33 & 2.32 & 2.76 & 2.34 & 2.01 & 2.59 & 2.57 & 2.41 & 2.35 & 2.52 \\
\hline
\end{tabular}

It was found that the macroeconomic and financial stabilization occurs mainly due to the functional component of the regulatory mechanism, the introduction of administrative tools of monetary regulation of banking activity, when the organizational and institutional components of the regulation predominantly have a longterm impact on the provision of financial and macroeconomic stability in the studied countries.

Thus, per survey findings, we formulate the following conclusions regarding specific countries. Just note that the list of countries under consideration was based on the data on the integrated indicator of the banking regulation intensity in 2001-2014 years. It can be divided into several groups.

The first group includes countries that have showed a relatively stable level of banking regulation intensity over the period of the study: Ukraine, the Russian Federation, Kazakhstan, Brazil, Poland, the USA, Chile, India, Estonia, Belarus. At the same time, countries such as Ukraine, Russia, Kazakhstan, Brazil, the USA, India, Estonia and Malaysia showed a gradual increase in the regulation intensity of banking activity on the part of the relevant authorities. So, in 2006, in Ukraine, there was a sharp decrease in IBRR indicator from 4.96 to 4.48 compared to the previous year mainly by reducing the rate of refinancing of banks from 14.7 to $11.5 \%$ and the rate of compulsory redundancy from 6 to $3 \%$. At the same time, the rate increase of compulsory redundancy from 6 to $9 \%$, as well as an overall reduction in the multi-branch banking in 2012 led to an increase in IBRR to $5.63 \%$ compared with $5.24 \%$ in the previous year.

The second group includes countries in which the banking regulation intensity is greatly fluctuated during the exploration period. They include: Canada, Colombia, the Netherlands, South Africa, the Philippines, and Nigeria.

The third group of countries, which showed a decrease in the level of banking activity intensity during 20012014, included only Morocco and Georgia.

The ambiguity of the nature and directions of influence of the regulation intensity of banking activity on the key indicators of the financial stability of banks retain the strategy to further banks regulation uncertain in order to ensure financial stability for the sake of business.

The determination of the optimal level of aggregate index of banking activity regulation involves the identification of the extremum point - Z-score, applied by the International Monetary Fund. The check of this function indicates the non-linearity and thus the absence of the extremum point, which indicates the need to increase the banking regulation intensity to ensure the financial stability. Since this strategy has negative effects for the banking business, it is necessary to use additional criteria related to the maximum consideration of business interests and sustainability of their financial condition. The integral index of financial stability of banks, which is based on the indicators characterizing the financial stability of the banks, is used in the model as an effective sign: the ratio of nonperforming loans to total loan portfolio of the banking system, Nonperf, the ratio of regulatory capital to assets, weighted by risk, Risk_weight, the ratio of the bank's own capital and reserves to total assets, Cap_assets, the profitability of the bank's capital, Ret_equit, the profitability of the bank's assets, Ret_assets and overhead costs of banks to the total assets of the banking system, Overhead. Given the existing methods for the display of integral indicator based on several related indicators are the following, the most popular ones are [1]:

$>$ the method of additive convolution of criteria;

$>$ the method of multiplicative convolution of criteria;

$>$ the method of uniform optimality.

The first two methods are not included in the category of so-called universal, because there are certain requirements to their use. Thus, the method of additive convolution of criteria is used in cases where we are confident that all our subjects of this indicator have linear and additive effect on the system. As a part of our investigation, we cannot accept this hypothesis positively, so the use of this method should be excluded. As 
for the second method, the method of multiplicative convolution of criteria, the main assumption here is the following - the basic convolution indicators should be relative values. Regarding the method of uniform optimality, there are no special requirements for its application. Given the specifics of our input indicators, to get the integrated indicator, we can use the last two methods, however, considering the popularity of its use in the financial sector, we turn our attention to the last one.

Before we get the value of the integral indicator, you need to go through several stages:

1. The determination of relevant indicators comprehensively describes a certain economic phenomenon and act as an input deck. After that it is necessary to organize data.

2. The optimization on input data via their filtration. Generally, it occurs by construction of correlation matrix, which allows us to identify dominant indicators and to avoid the phenomenon of multicollinearity.

3. The normalization of input data to avoid their size variation.

4. The construction of generalizable indicator. In our situation - it means to obtain the integral index of the of banking system stability (3).

$$
I I B S_{j}=\frac{\sum_{i=1}^{n} \hat{s}_{i j}}{\max \left\{\sum_{\substack{i=1 \\ j}}^{n} \hat{s}_{i j}\right\}},
$$

where $I I B S_{j}$ - an integral index of financial stability of banks for $\mathrm{j}$-th period of time; $\hat{s}_{i j}$ - the standard value of the i-th indicator for the $j$-th period of time.

First of all, you need to analyze these data on the presence / absence of multicollinearity to exclude from further study less important indicators. For this we construct the correlation matrix (Table 3); at the intersection of rows and columns we get the degree of dependence between parameters. The presence of high value of the correlation ratio ( 0.7 and above) will show that indicators are closely linked, and therefore they have equally strong influence on the economic situation of our study. Therefore, we can simplify the model by excluding the indicators, which will be characterized by multicollinearity.

Table 3. The correlation dependency matrix between financial stability indicators of banks

\begin{tabular}{|c|c|c|c|c|c|c|}
\hline Indexes & $\begin{array}{l}\text { The ratio of non- } \\
\text { performing loans } \\
\text { to total loan port- } \\
\text { folio of the bank- } \\
\text { ing system (\%), } \\
\text { Nonperf }\end{array}$ & $\begin{array}{l}\text { The ratio of } \\
\text { regulatory } \\
\text { capital to as- } \\
\text { sets weighted } \\
\text { for risk }(\%), \\
\text { Risk_weight }\end{array}$ & $\begin{array}{c}\text { The ratio of } \\
\text { bank equity and } \\
\text { bank reserves to } \\
\text { total assets (\%), } \\
\text { Cap_assets }\end{array}$ & $\begin{array}{c}\text { The } \\
\text { profitability } \\
\text { of the bank's } \\
\text { capital } \\
\text { (\% after } \\
\text { taxation), } \\
\text { Ret_equit }\end{array}$ & $\begin{array}{l}\text { The } \\
\text { profitability } \\
\text { of the } \\
\text { bank's as- } \\
\text { sets (\% } \\
\text { after } \\
\text { taxation), } \\
\text { Ret_assets }\end{array}$ & $\begin{array}{l}\text { Overhead ex- } \\
\text { penses to the total } \\
\text { assets of the } \\
\text { banking system } \\
(\%), \text { Overhead }\end{array}$ \\
\hline $\begin{array}{l}\text { The ratio of non-performing } \\
\text { loans to total loan portfolio in } \\
\text { the banking system (\%), } \\
\text { Nonperf }\end{array}$ & 1.00 & & & & & \\
\hline $\begin{array}{l}\text { The ratio of regulatory capital } \\
\text { to assets weighted for risk (\%), } \\
\text { Risk_weight }\end{array}$ & 0.21 & 1.00 & & & & \\
\hline $\begin{array}{l}\text { The ratio of bank equity and } \\
\text { bank reserves to total assets } \\
(\%), \text { Cap_assets }\end{array}$ & 0.28 & 0.77 & 1.00 & & & \\
\hline $\begin{array}{l}\text { The profitability of the bank's } \\
\text { capital (\% after taxation), } \\
\text { Ret_equit }\end{array}$ & 0.06 & 0.12 & 0.13 & 1.00 & & \\
\hline $\begin{array}{l}\text { The profitability of the bank's } \\
\text { assets (\% after taxation), } \\
\text { Ret_assets }\end{array}$ & -0.16 & 0.22 & 0.22 & 0.51 & 1.00 & \\
\hline $\begin{array}{l}\text { Overhead expenses to the total } \\
\text { assets of the banking system } \\
(\%) \text {, Overhead }\end{array}$ & 0.17 & 0.29 & 0.37 & 0.02 & 0.04 & 1.00 \\
\hline
\end{tabular}

As can be seen, there is no multicollinearity between one of the indexes, as the high value of correlation ratio equals to 0.51 (between bank profitability and capital assets), testifying the independence of these parameters 
from each other. This confirms the fact that this set of indicators will allow the best to describe the financial stability of banks. It is a testament to the fact that this setup of indicators allows describe the financial sustainability of banks.

At the third stage of determining the integral index, it is necessary to normalize the input data. As we have worked with them on previous studies, we have the following set of input data (Table 4).

Table 4. The input array of statistical data, which describe the banking system stability in 23 countries during 2001-2014 (fragment)

\begin{tabular}{|c|c|c|c|c|c|c|c|c|}
\hline Country & $\begin{array}{l}\text { Identification } \\
\text { number (ID) }\end{array}$ & Years & $\begin{array}{l}\text { The ratio of } \\
\text { non-per- } \\
\text { forming } \\
\text { loans to total } \\
\text { loan portfo- } \\
\text { lio of the } \\
\text { banking sys- } \\
\text { tem (\%), } \\
\text { Nonperf }\end{array}$ & $\begin{array}{l}\text { The ratio of } \\
\text { regulatory } \\
\text { capital to } \\
\text { assets } \\
\text { weighted } \\
\text { for risk } \\
\text { (\%), } \\
\text { Risk_weight }\end{array}$ & $\begin{array}{l}\text { The ratio of bank } \\
\text { equity and bank re- } \\
\text { serves to total assets } \\
(\%), \text { Cap_assets }\end{array}$ & $\begin{array}{l}\text { The } \\
\text { profitability } \\
\text { of the } \\
\text { bank's } \\
\text { capital (\% } \\
\text { after } \\
\text { taxation), } \\
\text { Ret_equit }\end{array}$ & $\begin{array}{l}\text { The } \\
\text { profitability } \\
\text { of the } \\
\text { bank's } \\
\text { assets } \\
\text { (\% after } \\
\text { taxation), } \\
\text { Ret_assets }\end{array}$ & $\begin{array}{l}\text { Overhead ex- } \\
\text { penses to the } \\
\text { total assets of } \\
\text { the banking } \\
\text { system }(\%), \\
\text { Overhead }\end{array}$ \\
\hline Ukraine & 1 & 2001 & 0.694 & 0.472 & 0.458 & 0.219 & 0.722 & 0.101 \\
\hline Ukraine & 1 & 2002 & 0.604 & 0.379 & 0.425 & 0.197 & 0.714 & 0.022 \\
\hline Ukraine & 1 & 2003 & 0.783 & 0.283 & 0.338 & 0.237 & 0.737 & 0.055 \\
\hline Ukraine & 1 & 2004 & 0.830 & 0.338 & 0.393 & 0.225 & 0.734 & 0.059 \\
\hline Ukraine & 1 & 2005 & 0.150 & 0.276 & 0.342 & 0.230 & 0.736 & 0.051 \\
\hline Ukraine & 1 & 2006 & 0.106 & 0.248 & 0.375 & 0.218 & 0.726 & 0.049 \\
\hline Ukraine & 1 & 2007 & 0.078 & 0.238 & 0.313 & 0.223 & 0.727 & 0.069 \\
\hline Ukraine & 1 & 2008 & 0.103 & 0.241 & 0.360 & 0.191 & 0.711 & 0.050 \\
\hline Ukraine & 1 & 2009 & 0.376 & 0.383 & 0.367 & 0.000 & 0.599 & 0.059 \\
\hline Ukraine & 1 & 2010 & 0.421 & 0.476 & 0.422 & 0.135 & 0.679 & 0.059 \\
\hline Ukraine & 1 & 2011 & 0.404 & 0.410 & 0.429 & 0.087 & 0.666 & 0.071 \\
\hline Ukraine & 1 & 2012 & 0.455 & 0.381 & 0.437 & 0.213 & 0.719 & 0.099 \\
\hline Ukraine & 1 & 2013 & 0.353 & 0.388 & 0.438 & 0.180 & 0.704 & 0.051 \\
\hline Ukraine & 1 & 2014 & 0.463 & 0.365 & 0.402 & 0.181 & 0.706 & 0.060 \\
\hline Germany & 2 & 2001 & 0.123 & 0.172 & 0.051 & 0.209 & 0.714 & 0.017 \\
\hline Germany & 2 & 2002 & 0.134 & 0.197 & 0.040 & 0.185 & 0.710 & 0.017 \\
\hline Germany & 2 & 2003 & 0.139 & 0.186 & 0.044 & 0.156 & 0.707 & 0.018 \\
\hline Germany & 2 & 2004 & 0.131 & 0.186 & 0.036 & 0.183 & 0.711 & 0.015 \\
\hline Germany & 2 & 2005 & 0.109 & 0.179 & 0.040 & 0.230 & 0.716 & 0.013 \\
\hline Germany & 2 & 2006 & 0.089 & 0.190 & 0.047 & 0.226 & 0.716 & 0.013 \\
\hline Germany & 2 & 2007 & 0.070 & 0.203 & 0.047 & 0.246 & 0.718 & 0.012 \\
\hline Germany & 2 & 2008 & 0.075 & 0.228 & 0.055 & 0.153 & 0.707 & 0.010 \\
\hline Germany & 2 & 2009 & 0.084 & 0.269 & 0.065 & 0.178 & 0.710 & 0.012 \\
\hline$\ldots$ & $\ldots$ & $\ldots$ & $\ldots$ & $\ldots$ & $\ldots$ & $\ldots$ & $\ldots$ & $\ldots$ \\
\hline
\end{tabular}

Having all necessary information on the array of input data, we can find the integral index of financial stability. The interpretation of a given integral index should be performed inside each country, as during examination the panel data for 23 countries were used, which are largely different from each other in their level of economic development. Having the meaning of integral index, we can proceed to the construction of evaluation model of interdependence between the integral index of financial sustainability in banks and IIBS indexes, characterizing the banking system in all, the economic status of the countries studied, as well as the process of regulation of the banking system: the concentration ratio of assets in 5 country's biggest banks, Cons 5 , the ratio of bank deposits to GDP, Dep_GDP, assets of the central bank in GDP, Centr_asset, the ratio of government loans and state-owned enterprises in GDP, Cred_govern, the ratio of private bank loans to GDP, Priv_cred, domestic credits, provided by the financial sector, as a percentage of GDP, Dom_cred, as well as aggregated index, describing the state regulation of banking business, IBRR. In the capacity of control variables, we will use the following indexes: the share of foreign banks in the banking system, Foreign_bank, Gross domestic product, GDP, the ratio of the difference between export and import of goods and services in the country to GDP, Trade.

Using the Hausman test, p-value of the test 0.0000 was obtained that confirms the hypothesis about the use of a model with fixed effects. Before proceeding to the construction of multivariate regression model with fixed 
effects, we offer to reduce the amount of input factors to identify which have a significant influence on the effective variable. For that let's use such tool as a principal components method (Principal Component Analysis). This method allows identify the dominant aggregated components in the model, consisting of different arrays of input data. Thus, ten components were obtained (based on the number of input parameters), the first three of which explain about $70 \%$ of the total set of values (Table 5).

In compliance with the principal components method the estimate of appropriated components is realized by the Kaiser criterion. The component, which eigenvalue is greater than one, participates in further investigation, though the others are simply dropped. In addition, it is important to pay attention to the percentage of the total variance, which accounts for each component - the more it is, the more the proportion of the total variance it explains, so indicators that are part of such a component describe the situation under study best of all. Thus, as can be seen from Table 5, the first three components correspond to these conditions, and the remaining six can be excluded from further consideration.

Table 5. The results of use of principal components method

\begin{tabular}{|c|c|c|c|}
\hline Component & Eigenvalues & The percentage of total variance & Cumulative percentage \\
\hline Component 1 & 2.713 & 30.14 & 30.14 \\
\hline Component 2 & 2.116 & 23.51 & 53.66 \\
\hline Component 3 & 1.318 & 14.64 & 68.30 \\
\hline Component 4 & 0.940 & 10.45 & 78.75 \\
\hline Component 5 & 0.728 & 8.09 & 86.84 \\
\hline Component 6 & 0.540 & 6.0 & 92.84 \\
\hline Component 7 & 0.330 & 3.67 & 96.52 \\
\hline Component 8 & 0.222 & 2.47 & 98.99 \\
\hline Component 9 & 0.091 & 1.01 & 100 \\
\hline
\end{tabular}

Except appropriated components, the principal components method makes it possible to see which input parameters are assigned to each of them (Table 6). If the value is larger than 0.3 in absolute value within one component, it is important as to this component.

Different colored values of corresponding indicators testify that they are significant within a component.

Table 6. The principal components and distribution of input parameters of research in them

\begin{tabular}{|l|c|c|c|}
\hline \multicolumn{1}{|c|}{ Indicator } & Component 1 & Component 2 & Component 3 \\
\hline $\begin{array}{l}\text { The indicator of assets concentration in 5 coun- } \\
\text { try's biggest banks, Cons5 }\end{array}$ & -0.0044 & -0.3314 & 0.3643 \\
\hline The ratio of bank deposits to GDP, Dep_GDP & 0.4955 & -0.1263 & 0.2661 \\
\hline Assets of the central bank in GDP, Centr_asset & 0.0073 & 0.4672 & 0.1717 \\
\hline $\begin{array}{l}\text { The ratio of government loans and state-owned } \\
\text { enterprises in GDP, Cred_govern }\end{array}$ & 0.2066 & 0.3030 & -0.0470 \\
\hline $\begin{array}{l}\text { The ratio of private bank loans to GDP, } \\
\text { Priv_cred }\end{array}$ & 0.4831 & -0.2938 & 0.1670 \\
\hline $\begin{array}{l}\text { Aggregated index, describing the state regulation } \\
\text { of banking business, Gov_reg }\end{array}$ & 0.3222 & 0.3018 & -0.3203 \\
\hline $\begin{array}{l}\text { Domestic credits, provided by the financial sec- } \\
\text { tor, as a percentage of GDP, Dom_cred }\end{array}$ & 0.5203 & -0.1345 & 0.2140 \\
\hline $\begin{array}{l}\text { The share of foreign banks in the banking sys- } \\
\text { tem, Foreing_bank }\end{array}$ & 0.0117 & 0.1212 & -0.4064 \\
\hline Gross domestic product, GDP & 0.3221 & 0.3386 & 0.1841 \\
\hline $\begin{array}{l}\text { The ratio of the difference between export and } \\
\text { import of goods and services in the country to } \\
\text { GDP, Trade }\end{array}$ & -0.0076 & -0.5099 & \\
\hline
\end{tabular}

Since our goal is to identify the relationship between the main indicators of banking regulation and financial sustainability in banks, we suggest choosing the parameters of another component for the construction of a regression model. This set of indicators, in our opinion, fully reflects the process of regulation of the banking system, including indicated control variables. The received model will be as follows (equation 4): 
IIBS $=0.452+0,069 \cdot I B R R-0.037 \cdot$ Cons $5+0.273 \cdot$ Centr_asset +

$0.049 \cdot$ Cred_govern $_{-0.271 \cdot G D P-0.004 \cdot \text { Trade. }}$

As it can be seen, assets of the central bank in the GDP, Centr_asset and Gross Domestic Product, GDP have the greatest influence on effective variable IIBS. However, the only parameter of the model for the index Centr_asset (the value of calculated t-test is equal to 5.84 at the $p$-value of 0.000 ) is statistically significant at that. However, the value of determination coefficient $R^{2}-0.69$ shows a significant constraint level between the independent and dependent variables, so it is also to consider the significance of the model parameters for these variables.

During the study of the nature of communication between an effective variable IIBS and Centr_asset, it was detected that it has a non-linear form (Figure 1, see in Appendix).

According to this figure, it is clear that it is similar to the inverted parabola that is a cubic function. We have also used the built-in function Stata utest, through which we confirm the presence of non-linear dependence, reversed parabola ( $p$-value is 0.002 , allowing us to confirm the null hypothesis relatively the presence of reversed parabola), the extremum point at that is at the level of the indicator Centr_asset 0.426 . To verify whether it is in fact, we introduce cubed indicator Centr_asset to our model. We obtain the following model (equation 5):

$$
\begin{aligned}
& I I B S=0.423+0.079 \cdot I B R R-0.031 \cdot \text { Cons } 5-0.236 \cdot \text { Centr_asset }^{3}+ \\
& 0.048 \cdot \text { Cred_govern }^{2} 0.088 \cdot \text { GDP }-0.02 \cdot \text { Trade. }
\end{aligned}
$$

As you can see, with the introduction of adjusted value of the indicator Centr_asset, we got slightly smaller values for the coefficients in this model; at that the value of determination coefficient $R^{2}$ has been improved to 0.697. In our model, there is also an important integral index reflecting the state regulation of banking activity - an aggregated index IBRR. As can be seen in the latest model 5, it has a slight positive effect on the performance indicator (0.079) and is not statistically significant (the value of calculated t-test is equal to 1.69 at the p-value of 0.093). However, constructing a plot of integrated index of this indicator, we also have found a non-linear relationship (Figure 2).

The results of using utest function confirm the quadratic relationship between IIBS and IBRR, the extremum point at that is at the level of the IBRR index and comprises 0.537 . So, the final form of the model under study is as follows (6):

$$
\begin{aligned}
& I I B S=0.339-0.407 \cdot \text { IBRR }^{2}-0.030 \cdot \text { Cons } 5-0.256 \cdot \text { Centr_asset }^{3}+ \\
& 0.035 \cdot \text { Cred__overn }^{2} 0.016 \cdot G D P+0.019 \cdot \text { Trade }
\end{aligned}
$$

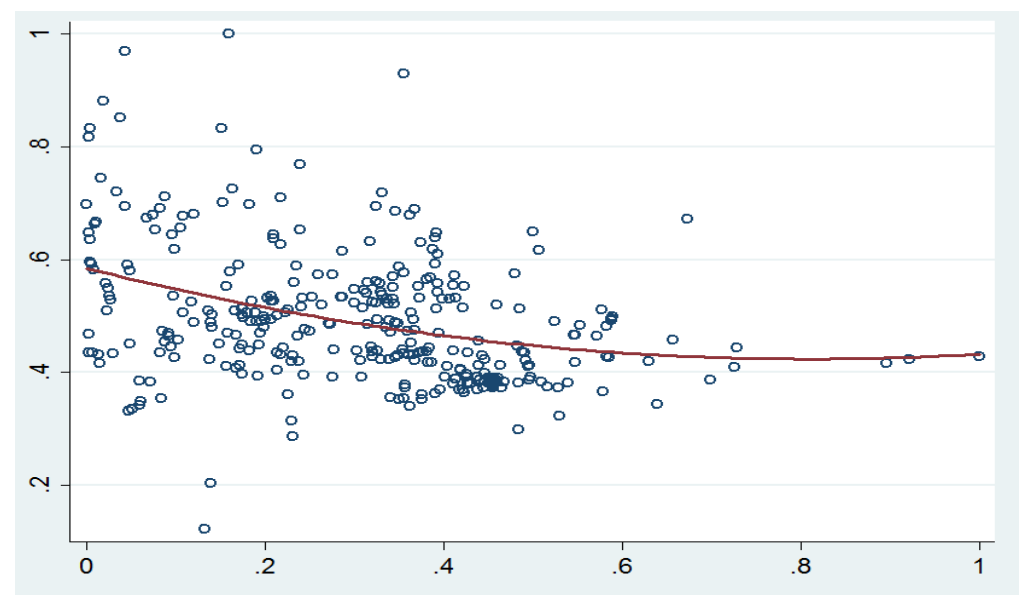

Figure 2. Graphical display of the relationship between the integral index of the financial sustainability of banks, $I I B S$ and aggregated index, describing the state regulation of banking business, IBRR

Source: fragment from the program Stata 12 / SE.

So, we have received the final form of the model, the results of which are described by the determination coefficient $R^{2}$, which is equal to 0.7. This shows a high level of connection between the independent and dependent variables. Statistically significant indicator which reflects the share of assets of the central bank in GDP, Centr_asset (the value of calculated $t$-test is -3.00 at $p$-value of 0,003), and an aggregated index of the 
state regulation of banking activity, IBRR (the value of calculated $t$-test is -2.53 at $p$-value of $p$-0.012). The other parameters are not statistically significant and are of linear character of interaction with an effective indicator. Thus, the optimal level of intensity regulation is set at 0.537 because of the extremum search. The increase of intensity regulation of banks to the level of intensity IBRR 0.537 reduces the financial sustainability of banks (unfavorable zone), after reaching a level IBRR 0.537 - has a positive effect on the financial sustainability of banks (the favorable zone).

\section{Conclusion and discussion}

The study conducted show the presence of the optimal level of banking activity regulation to maintain the financial stability of the banking sector. Practical calculations for this model in the work is carried out based on data for 23 countries (Ukraine, Russia, Belarus, France, Germany, Great Britain, Poland, Estonia, the Netherlands, Georgia, Kazakhstan, India, Malaysia, the Philippines, Canada, the United States, Colombia, Brazil, Morocco, Nigeria, South Africa, Australia, Chile) for the 2001-2014. It has allowed establishing the quantitative limits of the zone of unbeneficial influence and good influence of intensity regulation growth over the financial sustainability of banks. Calculations have shown that the boundary between these zones corresponds to the intensity regulation indicator of banking activity at the level of 0.53 . Findings can be the basis for the development of measures on of banking activity regulation, depending on the current state of the financial sustainability of banks, which, in turn, requires a more detailed study of the impact of banking activity regulation to meet the interests of the owners and top management of the banking business.

\section{Recommendations for further research}

The prospective lines of development of science topics are the investigation of separate regulatory measures on the part of the central bank and other official bodies in the context of their impact on the banking system stabilization, search for the most effective anti-crisis instruments and identification of time periods during which a compliance with a certain level of bank intensity regulation is the most effective.

\section{References}

1. Ajvazian, S.A., and Mkhiratian, V.S. (1998). Prikladnaya statistica i osnovy econometriki [Applied Statistics and Fundamentals of Econometrics], Moscow: UNITI, 1022 p.

2. Arbusov, S.G., Kolobov, Yu.V., Mishchenko, V.I., and Naumenkova S.V. (2011). Bankivska entsyklopedija [Bank encyclopedia]. Research Center of National Bank of Ukraine: Knowledge, 504 p.

3. Barth, James R., Luis G. Dopico, Daniel E. Nolle, and James A. Wilcox (2001). Bank Safety and Soundness and the Structure of Bank Supervision: A Cross-Country Analysis, 2001 Annual Meeting Toronto, Canada, October 18, $55 \mathrm{p}$.

4. Belova, I.V., Bashlaj, S.V. (2013). Vyznachennia finansovoji stabilnosti Ukrajiny [The definition of financial stability Ukraine], Visnyk Natsionalnogo banku Ukrajiny [Bulletin of the National Bank of Ukraine], 7, 25-31.

5. Central bank of Belarus [Online]. Retrieved from http://www.nbrb.by/.

6. Central Bank of Brazil [Online]. Retrieved from http://www.bcb.gov.br/pt-br/paginas/default.aspx.

7. Central Bank of Canada [Online]. Retrieved from http://www.bank-banque-canada.ca/index.html.

8. Central Bank of Chili [Online]. Retrieved from http://www.bcentral.cl/index.asp.

9. Central Bank of Estonia [Online]. Retrieved from http://www.eestipank.ee/.

10. Central Bank of Georgia [Online]. Retrieved from https://www.nbg.gov.ge/index.php?m=2.

11. Central Bank of Germany [Online]. Retrieved from http://www.bundesbank.de/Navigation/DE/Home/home_node.html.

12. Central Bank of India [Online]. Retrieved from http://www.rbi.org.in/scripts/BS_ViewBulletin.aspx? $\mathrm{Id}=10964$.

13. Central Bank of Kazakhstan [Online]. Retrieved from http://www.nationalbank.kz/?\&switch=kazakh.

14. Central Bank of Malaysia [Online]. Retrieved from http://www.bnm.gov.my/.

15. Central Bank of Nigeria [Online]. Retrieved from http://www.cenbank.org/.

16. Central Bank of Philippines [Online]. Retrieved from http://www.bsp.gov.ph/.

17. Central Bank of Poland [Online]. Retrieved from http://www.nbp.pl/.

18. Central Bank of Russia [Online]. Retrieved from http://www.cbr.ru/

19. Central Bank of the Netherlands [Online]. Retrieved from http://www.dnb.nl/index.htm. 
20. Central Bank of United Kingdom [Online]. Retrieved from http://www.bankofengland.co.uk/Pages/home.aspx.

21. Central Bank of United States of America [Online]. Retrieved from http://www.federalreserve.gov/.

22. Goodhart, C. (2015). Linkages between macro-prudential and micro-prudential supervision Butterworths, Journal of International Banking and Financial Law, 30(10), 607-609.

23. Kovalenko, V., Garkusha, Yu. (2013). Teoretychni ta metodychni pidhody do otsiniuvannia finansovoji stabilnosti bankivskoji systemy [Theoretical and methodological approaches to the assessment of financial stability of the banking system], Visnyk Natsionalnogo banku Ukrajiny [Bulletin of the National Bank of Ukraine], 7, pp. 35-40.

24. Shahchera, M., Jouzdani, N. (2011). The impact of regulation on soundness banking, 2010 International Conference of Business and Economics Research, Vol. 1 (2011), IACSIT Press, Kuala Lumpur, Malaysia. Retrieved from: http://www.ipedr.com/vol1/33-B10014.pdf.

25. Tanda, A. (2015). The Effects of Bank Regulation on the Relationship between Capital and Risk, Comparative Economic Studies, 57(1), pp. 31-54.

26. The National Bank of Ukraine [Online]. Retrieved from http://www.bank.gov.ua.

27. The World Bank [Online]. Retrieved from http://www.worldbank.org/.

\section{Appendix}

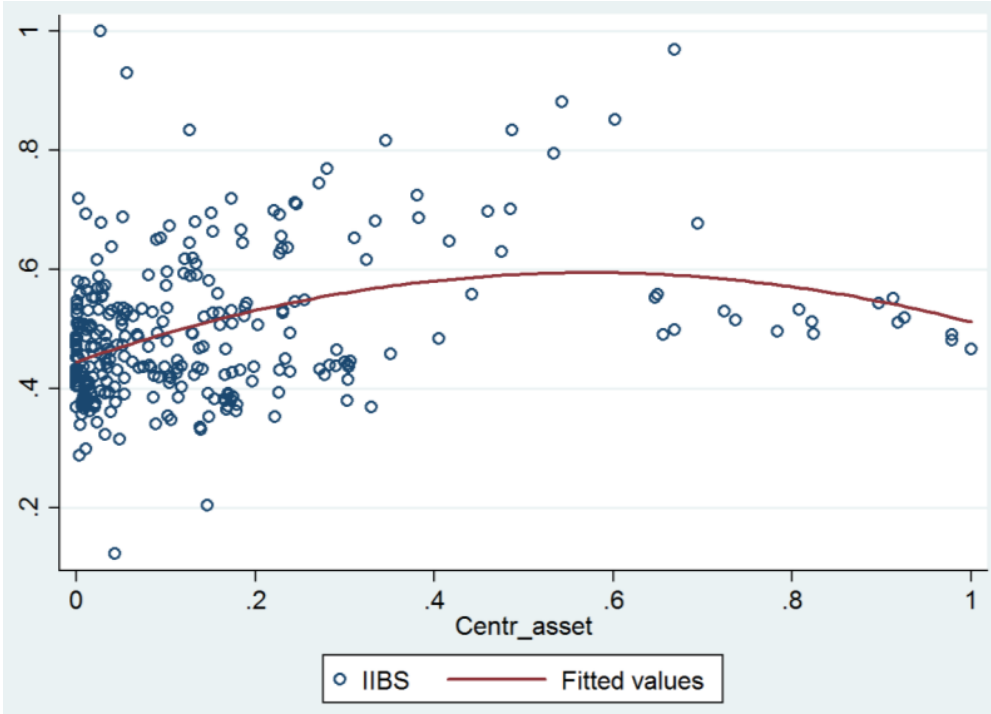

Figure 1. Graphical display of the relationship between the integrated index of the financial sustainability of banks, IIBS and assets of the central bank GDP, Centr_asset (fragment from the program 12 Stata / SE) 